\title{
Jacobus Capitein: Champion for Slavery and Resisting Mimic?
}

\author{
HENDRIK L. BOSMAN (STELLENBOSCH UNIVERSITY)
}

\begin{abstract}
Jacobus Eliza Johannes Capitein (1717-1747) was a man of many firsts - the first black student of theology at the University of Leiden in the Netherlands, the first black minister ordained in the Dutch Reformed Church in the Netherlands, the author of the first Fante/Mfantse-Dutch Grammar in Ghana as well as the first translator of the Ten Commandments, Twelve Articles of Faith and parts of the Catechism into Fante/Mfantse. However, he is also remembered as the first African to argue in writing that slavery was compatible with Christianity in the public lecture that he delivered at Leiden in 1742 on the topic, De Servitute Libertati Christianae Non Contraria. The Latin original was soon translated into Dutch and became so popular in the Netherlands that it was reprinted five times in the first year of publication. This contribution will pose the question: Was Capitein a sell-out who soothed the Dutch colonial conscience as he argued with scholarly vigour in his dissertation that the Bible did not prohibit slavery and that it was therefore permissible to continue with the practice in the eighteenth century; or was he resisting the system by means of mimicry due to his hybrid identity - as an African with a European education - who wanted to spread the Christian message and be an educator of his people?
\end{abstract}

KEYWORDS: JEJ Capitein, Bible and slavery, hybridity, mimicry

\section{A INTRODUCTION}

The discussion is aimed as a response to David Adamo's plea that African Biblical Studies must be "postcolonial" and his call for the interpretation of the Bible that enables "transformation in Africa." It will be argued that a

* Submitted: 28/04/2021; peer-reviewed: 15/06/2021; accepted: 30/07/2021. Hendrik Bosman, "Jacobus Capitein: A Champion for Slavery and Resisting Mimic?" 34 no. 2 (2021): 628 - 645. DOI: https://doi.org/10.17159/2312-3621/2020/v34n2a18.

1 David T. Adamo, “African Biblical Studies: Illusions, Realities and Challenges," In die Skriflig 50/1 (2016): 1, 5. This contribution is made as a token of appreciation of Prof Adamo's contributions towards furthering Old Testament Studies in West Africa 
"postcolonial" critique of "coloniality," as the lingering impact of colonialism on current African contexts, can be informed by the life and work of Reverend Jacobus Eliza Johannes Capitein (1717-1747) — an African with an European education who in some ways used his hybrid identity to resist the negative impact of slavery and mercantile colonialism in West Africa.

To begin, a short biographical outline provides the eighteenth-century context within which Jacobus Capitein wrote his defence of slavery and did pioneering translations of basic Christian texts in the local vernacular for the benefit of the education of children entrusted to his care. Then his defence of the right of Christians to keep slaves will be evaluated against the background of his translations into Fante or Mfantse of the Ten Commandments, the Lord's Prayer, and the Apostles' Creed, as well as some of his letters written during the time that he set up a school and an orphanage in Elmina (in present-day Ghana). In the conclusion, it will be asked whether a champion of slavery could have been an agent of transformation when confronted by the realities and challenges of his African context and whether current decolonisation projects can glean from Capitein's tragic biography.

\section{B SHORT BIOGRAPHY OF JACOBUS CAPITEIN}

Jacobus Elisa Johannes Capitein, whose African name is not known, was born c. 1717 in the Dutch Gold or Guinea Coast (known today as Ghana). ${ }^{2}$ It is possible that Capitein was a mulatto with a Dutch father and a local (Fante?) mother, but this has not been established beyond any doubt. ${ }^{3}$

and, on a more personal note, for assisting my visit to Nigeria to participate in a NABIS conference in 2006.

2 David N.A. Kpobi, Mission in Chains: The Life, Theology, and Ministry of the Exslave Jacobus EJ Capitein (1717-1747) (Zoetermeer: Boekencentrum, 1993), 53-54 refers to the speculation about Capitein's African name - in the original Latin version of his 1742 dissertation, Capitein is referred to as "Jacobus Elisa Joannes Capitein, Afer." This enigmatic reference to "Afer" was linked by some historians to a rumour about an African called "Asar" who studied in the Netherlands, returned to the Gold Coast as a minister of religion and eventually renounced Christianity. Grant Parker, The Agony of Asar: A Thesis on Slavery by the Former Slave, Jacobus Elisa Johannes Capitein 1717 - 1747 (Princeton: Marcus Wiener, 2001), 10, 159, also refers to the nineteenth century rumour about "Asar" and suggests that "the name is a mistaken distortion of the name, Afer, the Latin for "African" due to the general confusion of the letters "f" and "s" in eighteenth century print type. However, it should be noted that the Dutch translation of "Afer" was "Afrikaansche Moor" ("African Moor") and this does not suggest any reference to an original personal name.

3 David K. Amponsah, "Christian Slavery, Colonialism and Violence: The Life and Writings of an African Ex-Slave, 1717-1747," JAR 1/4 (2013): 431, describes Jacobus Capitein as a "mulatto ex-slave" without giving any evidence that he was a "mulatto"a Portuguese and Spanish term for the child of Black and European parents. This was 
It is unclear why, as an eight-year-old, Capitein was sold in 1725 as a slave to a Dutch sea captain, Arnold (Aarnout) Steenhart. According to his "dissertation," it was a case of "parentis orbus" ("being robbed/stolen from my parents"). Captain Steenhart first took him for a short visit to the Netherlands and then returned to the Gold Coast. Shortly after his return, he gave Capitein to an old friend, Jacobus van Goch, who was a factor or trader in the Dutch West India Company (DWIC) trading post in Shama (at the former Portuguese military fort of San Sebastian) and who was widely known as a kind-hearted person. ${ }^{5}$ It is striking and somewhat ironic that van Goch named the eight-year-old in accordance with the occupation of his first owner ("capitein, that is, "captain" in Dutch).

Within three years, van Goch returned to the Netherlands and settled in Middelburg, which Capitein later described in a poem as "the door/gate to the paradise of the Netherlands." Soon van Goch and Capitein resettled in The Hague (birthplace of van Goch) and Capitein was provided a solid foundation in the Dutch language and taught the art of painting while also undergoing catechism. It was during his catechism classes that Capitein told some of his fellow students that he would like to show his people in the West Coast the way to salvation. When this longing was made known to his catechism teacher, van Goch was urged to allow Capitein access to good schooling to enable eventual theological training in preparation for the ministry. ${ }^{7}$

Capitein enrolled in the Latin school of The Hague and his education received support from his own rector, Isaac Valkenaar, and from some wellmeaning supporters outside the school such as the multi-gifted Miss F.C. Roscam, who provided him with a solid grounding in Greek, Latin and Hebrew so that he eventually became suitable for christening in July $1735 .^{8}$ At his christening, Capitein had to receive Christian names and it is striking that van

possible however since European traders in eighteenth-century West Africa often created alliances through marriage with local African people by means of a practice called "cassare" or "calisare" (derived from the Portuguese "to marry" - "casar"). Harvey M. Feinberg, "Africans and Europeans in West Africa: Eliminans and Dutchmen on the Gold Coast during the Eighteenth Century," TAPS 79/7 (1989): ix-x, 157 points out that the community at Elmina "included people of mixed descent, the offspring of European fathers and African mothers..." and that an "Afro-European population grew in Elmina..."

4 Jacobus E.J. Capitein, Dissertatio Politico-Theologica de Servitute, Libertati Christianae non contraria (Leiden: Academiae Typographos, 1742), 13.

5 Albert Eekhof, "De Negerpredikant Jacobus Elisa Joannes Capitein, Bijdrage tot de kennis van onze koloniale kerkgeschiedenis," NAK XII/2 (1916): 144.

6 Capitein, Dissertatio, XI. Later in this contribution, it will be pointed out that Middelburg was also the centre for the Dutch slave trade with the Caribbean.

7 Eekhof, "Capitein," 148.

8 Ibid., 149. 
Goch named the eighteen-year-old after himself and family members who were present as witnesses to the baptism. The first name came from his benefactor van Goch himself (Jacobus), the second (Elisa) from the sister of van Goch and the third (Johannes) from a niece of van Goch. ${ }^{9}$ Current research suggests that Capitein was the first African to be baptised in The Netherlands and it was considered a memorable event. ${ }^{10}$

After more than six years of schooling, Capitein delivered a public speech on the topic "The Calling of the Heathens" ("Roeping der heidenen") in which he set out the requirements for missionary work-learning the languages of heathens, identifying a suitable location for religious activities, reaching out to the people and establishing training for missionaries. ${ }^{11}$ Against this background, Capitein was allowed, aged twenty, to enter the University of Leiden in July 1737 to study theology at one of the most famous faculties in Europe. ${ }^{12}$

It is interesting to note that his benefactor, van Goch, left Capitein his own silver pocket watch and stipulated in his will that Jacobus Capitein be provided with clothing and nourishment while being instructed in Hebrew, Greek and Latin as well as the means to return to the Gold Coast after completing his studies. ${ }^{13} \mathrm{He}$ also received a stipend for five years from the prestigious Hallet Study Fund that was described as an "extraordinary scholarship" ("extraordinaris beursaal") to enable Capitein "to proclaim the gospel to his fellow countrymen" ( "om sijn landsluyden het Evangelium te gaan verkondigen"). This is important to note since it forms the background to the eventual presentation of his "Dissertatio." In his yearly report to the Hallet Fund, Capitein mentioned the outcome of some of his examinations - in 1739, he received a "reasonably well" ("tamelijk goed genoegen") for his Latin speech, while in 1741 his Greek and theology examinations had a similar outcome ("redelijk wel voldaan").

After his studies in 1742, Capitein was required to deliver a public dispute or "Dissertatio" in Latin to demonstrate his academic progress to the university examiners and the stewards of the Hallet bursary fund. ${ }^{14}$ Capitein was chosen to deliver this "public disputation" because of his good academic progress but the speech was also one of the conditions of the Hallet Study Fund. ${ }^{15}$ There has been a perennial debate amongst researchers whether Jacobus Capitein earned the degree "Doctor of Theology" on the basis of the "Dissertatio" that was delivered

9 Ibid., 149.

10 Kpobi, Mission in Chains, 58.

11 Eekhof, "Capitein," 150.

12 Kpobi, Mission in Chains, 59.

13 Eekhof, "Capitein," 151-152.

14 Ibid., 153-154.

15 Kpobi, Mission in Chains, 62. 
in compliance with the rules of the Hallet Study Fund. ${ }^{16}$ Despite the controversy about his status as "Doctor of Theology," there is no doubt that Capitein was a person of considerable erudition and well respected by his peers.

Soon after completing his theological studies at the University of Leiden, Capitein returned to West Africa and was appointed as minister at St George D'Elmina, also called Elmina (Portuguese for "the mine") or Edina, on the Gold Coast from 1742-1747. There are diverging reports on what transpired during his ministry. Albert Eekhof quotes several sources from the late eighteenth and the nineteenth century that made the following speculative claims ${ }^{17}$ that Capitein achieved little success in converting local populations to Christianity, that he died while travelling, killed by "heathen fellow tribal members" ( "heidensche stamgenooten"), and that he backslided and became a "blind servant of fetishism" ("een blinden Fetisch dienaar"). However, Eekhof rejects these speculative claims and sets out to conduct solid historical research based on available documents in this regard, amongst others the letter by the Director General of the Guinea that confirms the death of Capitein on 1 February 1747 and how he left his widow with an insolvent estate. ${ }^{18}$ One should take note also of the high mortality rate of employees of the Dutch West Indian Company on the Gold Coast, which makes it more likely that Capitein died of natural causes and further counters the speculative rumours about the events leading up to Capitein's death or disappearance. ${ }^{19}$

It is striking that several decades after his death Jacobus Capitein was remembered in both the Netherlands and Germany. In the Netherlands, besides the printing of his books and sermons, plate impressions of his likeness adorned some Dutch houses up to 1797 . He was also mentioned and discussed in two German surveys of scholars in Europe during his lifetime and after his death. ${ }^{20}$

16 Kpobi, Mission in Chains, 66-69, points out that there is no evidence that Capitein ever participated in the usual ceremony that accompanied the awarding of the doctorate and the University of Leiden has no record of him being awarded a doctorate.

17 Eekhof, "Capitein," 141-142.

18 Eekhof, "Capitein," 142, examined documents such as Capitein's letters to the WEIC and the Hallet Study Fund. P.A. Leupe, "De Latijnse Disseratie van den Predikant J.E.J. Capitein, 1742," Bijdragen tot de Taal-, Land-en Volkenkunde van Nederlandsch-Indië 28/1 (1880): 610, criticises the rumour that Capitein, soon after his return to Elmina, got rid of his "suit of civilization" ("beschawingspak") and returned to the forest to live amongst his folks and never to return to Elmina. These claims however are not substantiated by the official correspondence that verified his death in 1747.

19 Harvey M. Feinberg, "New Data on European Mortality in West Africa: The Dutch on the Gold Coast, 1719-1760," JAH 15 (1974): 357-371.

20 Ernst L. Rathlef, Geschichte Jeztlebender Gelehrten, als eine Fortsetzung des Jeztlebenden Gelehrten Europa (Zelle: Deetz, 1743), 159-171, provides a 12-page description of his dissertation. Johann C. Strodtmann, Das Neue Gelehrte Europa 
To understand why Capitein, as an educated freed slave, made such an impact on Dutch society, more attention must be given to the culture that was prevalent in the Netherlands during the eighteenth century. Although the seventeenth century is usually considered the "Golden Age" of the Netherlands, the first half of the eighteenth century was in many ways a continuation thereof. Simon Schama depicted Dutch culture during the "Golden Age" as an "embarrassment of riches" and that it established a society in which social status was largely determined by income and material wealth; but it also developed religious tolerance that made the Netherlands a place of refuge for Jewish merchants driven from Portugal and Huguenots persecuted in France. ${ }^{21}$ Herman Pleij responds however by describing the so-called "Golden Age" as "Het Nederlandse Onbehagen" or "The Dutch Embarrassment." He notes that the Dutch replaced Spain and Portugal as major player in the slave trade during the seventeenth century and that the shipping and selling of slaves from Africa to the Americas made a significant contribution to the wealth of the Netherlands during the "Golden Age" and thereafter. ${ }^{22}$

In the past two decades, there has been a rigorous debate on the impact of slavery on Dutch affluence, which has caused a radical rethinking of the socalled "Golden Age." 23 In 2001, the Dutch politician, Andre Kramp, argued that there was a "conspiracy of silence" regarding the Dutch participation in the slave trade of previous centuries and this should be rectified as soon as possible. ${ }^{24}$ Kramp was responding to longstanding self-congratulatory presupposition that it is "typically Dutch" to maintain a tolerant and inclusive humanism without acknowledging past complicity in the slave trade. ${ }^{25}$ The recent controversy in 2021, which related to the exhibition of the royal "Golden Coach" in Amsterdam,

(Wolfenbüttel: Th XII, 1758), 162-164, discusses not only his dissertation but also two of his sermons as examples of his renown as a preacher.

21 Simon Schama, The Embarrassment of Riches: An Interpretation of Dutch Culture in the Golden Age (New York: Alfred Knopf, 1987).

22 Herman Pleij, Het Nederlandse Onbehagen (Amsterdam: Prometheus, 1991).

23 Karel Schoeman, Portrait of a Slave Society. The Cape of Good Hope, 1717-1795 (Pretoria: Protea Book House, 2012), 1072, agrees that it is "only recently that the Dutch have begun to pay attention to their own responsibility for slavery and participation in the slave trade." He mentions the recent establishment of a "National Institute for the Study of Dutch Slavery and Its Legacy" as well as the erection of monuments commemorating slavery in Amsterdam and Middelburg (the centre of the slave trade between West Africa and the Caribbean).

24 Markus Balkenhol, "Silence and the Politics of Compassion: Commemorating Slavery in the Netherlands," Social Anthropology 24/3 (2016): 281.

25 Balkenhol, "Silence and the Politics of Compassion," 278. 
indicates that owning up to past racism by the Dutch society is still an ongoing project. $^{26}$

\section{DISSERTATION ON SLAVERY BEING COMPATIBLE WITH BIBLE}

Capitein was quite a productive writer and, within a few years, he had published several collections of sermons and letters that will be discussed briefly in the next section. However, the focus of this contribution is on his most influential publication, the "dissertation" published in 1742 on the topic, "Dissertatio Politico-Theologica de Servitute, libertati christianae non contraria,"27 translated into Dutch with the title, "Staatkundig-Godgeleerd Onderzoekschrift over de Slaverny, als niet strydig tegen de Christlyke Vryheid." 28 Since the reading of the Latin original and Dutch translation might be challenging for most readers of this contribution, it was decided to make use of the excellent English translation of the "Dissertatio" published by Grant Parker in 2001. ${ }^{29}$

As argued above, the Hallet bursary or study fund expected that the beneficiaries deliver a public dispute or address ("Dissertatio") in Latin and for this purpose Capitein received additional funding of 25 guilders. Some scholars seem to interpret the concept "Dissertatio" as an indication that Capitein graduated as a "theologiae doctor" from the University of Leiden. This is an incorrect and anachronistic assumption due to the modern depiction of the scholarly research required for a doctoral degree as a "dissertation." 30

The "Dissertatio" or public lecture was systematically presented with the following sections or chapters, introduced by an informative short autobiography (Praefatio ad Lectorem/"Preface to the Reader"). ${ }^{31}$ This

26 In 1896, the "Golden Coach" was presented as a gift to the young Dutch Queen Wilhelmina with a side panel called "Tribute of the Colonies" depicting kneeling black people handing over produce like cacao and sugarcane to white people. In the same panel, a young white boy is seen presenting a book to a young black boy, with the book representing "civilisation" (New Age Entertainment, August 4, 2021). The symbolism of the black boy receiving "civilisation" resonates with the young Capitein receiving a Dutch education that enabled him to argue for the co-existence of Christian freedom and slavery and the ongoing servitude of blacks in Dutch colonies and trading posts such as Elmina.

27 Capitein, Dissertatio, 1742.

28 Jacobus E.J. Capitein, Staatkundig-Godgeleerd Onderzoekschrift over de Slaverny, als niet strydig tegen de Christlyke Vryheid (3 ed.; Amsterdam: G de Groot, 1742).

29 Some important concepts are referred to in Latin or the initial translation into Dutch. 30 Eekhof, "Capitein," 153-154.

31 Kpobi, Mission in Chains, 104, points out that Capitein begins with a reference to his earlier "treatise" with the title "The Call of the Heathen" (De Vocatione Ethnicorum) that advocated missionary work among non-believers, with the possible implication that the conversion of heathens should lead to them being freed from slavery, since believers should not be enslaved. 
"Preface" suggests that Capitein adhered to some form of eighteenth-century dispensationalism because his point of departure is to live in obedience to the nature of the New Covenant or New Dispensation according to which the worship of God was no longer restricted to one place or one race. To verify his point, he quotes Hosea 2:23 ("I will say to those who are not my people. 'You are my people") as well as Joel 2:28 ("Then afterward I will pour out my spirit on all flesh"). ${ }^{32}$ These Old Testament prophecies were cited also by Peter in his speech at Pentecost in Acts 2 and motivated Capitein to work towards his missionary ideals of proclaiming the Christian message to all people, as he attempted to do at Elmina. The biblical interpretation illustrated by Capitein's references to these Old Testament texts supports the assumption that the eighteenth century "was the period of the direct reading of the "plain' text" (sensus plenior). ${ }^{33}$ According to dispensationalism, this New Covenant will be facilitated in the future with the coming of the Messiah to establish a kingdom that will extend to the furthest shores of the world. ${ }^{34}$

In the first chapter, slavery is defined in such a way that any voluntary enslavement should rather be considered as servitude and not as slavery, thus, the overall argument is summarised. ${ }^{35}$ This appeal to classic philosophers such as Seneca is typical of the rationalism that permeated the intellectual discourse of the eighteenth century. ${ }^{36}$

The ancient origin of slavery is pointed out in the second chapter and it is argued that all societies in the past have made use of slavery. Capitein was aware of the diverging opinions of when slavery originated but he dismissed this divergence as "conjectures" and agreed with those who accepted "that slavery arose soon after the flood." 37 While accepting Moses as the author of Genesis, Capitein referred to Gen 9:25 as the reason for his conviction that slavery began after the flood. In a brief but seminal argument, Capitein stated that, "because Ham mocked his father's nudity, the descendants of Ham, who had this

32 Parker, Agony of Asar, 83.

33 Hans W. Frei, The Eclipse of Biblical Narrative: A Study in Eighteenth and Nineteenth Century Hermeneutics (New Haven: Yale University Press, 1974), 55.

34 Capitein quotes Zech $14: 9$ as verification of a time in future when all will acknowledge the Lord.

35 Kpobi, Mission in Chains, 105, refers to the quotation from Seneca that "it is a person's will that determines whether he becomes a slave or not" - the implication is that slave is one who "serves another person against his or her will," while "a servant does so willingly."

36 Capitein quoted Cicero from "On Duties 1.7" where he pointed out that "every argument about something which is rationally undertaken should proceed from a definition so that it is understood what is being disputed," according to Andrew R. Dyck, A Commentary on Cicero, 'De Officiis' (Ann Arbor: University of Michigan Press, 1996).

37 Parker, Agony of Asar, 99. 
miserable condition imposed on him before his brothers, would bear the mark of perpetual punishment, so that he would be a 'slave of slaves to his brothers' (eved avadim l'echayu)." 38 It is ironical that Gen 9:25 does not refer to the cursing of Ham but to the cursing of his son, Canaan. Parker provides an informative discussion of the Dutch theological context within which slavery is not linked to the Fall in Gen 3 but to the so-called curse of Ham in Gen 9 that "magnifies the Fall" as well as the presentation of Africans as "sons of Ham." 39

Although the Bible does not refer to skin colour in Gen 9 (the story of Noah and his sons), the biblical narrative was reformulated over centuries to change the cursing of Canaan to become a slave (anticipating the occupation of the Promised Land by the Israelites) into the cursing of Ham as an etiological "origins myth" that explained "the existence of black slavery." 40 The development of a dual curse of Ham (being both black and a slave) seems to be the result of "historical forces affecting black Africans." For example, "the enslavement of blacks in ancient times, the Muslim conquests of North Africa, the commercial and cultural influences of Islam on Christian Europe," and last but not the least, "the development of the Atlantic slave trade (that) gave birth to the gradual and diverse expressions linking blackness and slavery, culminating in the Curse of Ham." 41

Furthermore, Capitein quoted Lev 25:45-46 as a divine instruction that slavery was an acceptable societal practice although he pointed out that the right to free slaves was also allowed by this biblical injunction. ${ }^{42}$ In view of Lev 25 , Capitein concluded that, "it was up to the Jews whether they wished to keep their slaves (avadim) in ongoing servitude... if only any master take care that, incensed with anger, he does not break the limbs of a slave or maidservant with a cruel flogging." 43 It is clear that Capitein did not advance any argument in favour of the abolition of slavery as an institution but rather opted for a more humane approach towards slaves and enslavement.

\footnotetext{
38 Ibid., 99.

39 Ibid., 61-65.

40 David M. Goldenburg, Black and Slave: The Origins and History of the Curse of Ham (Berlin: De Gruyter, 2017), 1.

41 Goldenburg, Black and Slave, 199.

42 In view of this article's focus on Old Testament references, it must be acknowledged that the majority of Capitein's biblical quotes come from the New Testament. He argued that the Law of Moses (Old Testament) has been replaced by the "New Covenant" (New Testament) that finds spiritual enslavement unacceptable but does not oppose physical slavery (1 Cor 3:17; 7:23; Gal 5:1 and the Letter to Philemon). 43 Parker, Agony of Asar, 102: "When this happened, according to Exodus 21:26-27, a slave and maidservant were to be set free by a decision of the court, even against the master's wishes."
} 
The gist of his "dissertation" is found in the third chapter that presents the argument that Christianity and slavery need not be considered antithetical. One is impressed by the breadth of his scholarship reflected in the wide-ranging quotes from biblical, classical and philosophical sources - but in this chapter, no direct reference is made to the Old Testament. Reference is made, in passing to the golden calf episode in Exod 32-34, as an example of the Old Covenant. Against the background of the juxtaposition of the letter of the Law of Moses (that was transgressed by the Israelites when they worshipped the golden calf at Sinai) with the spirit of the love of God according to 2 Cor 3:6, "with the aphorism, the letter kills, but the spirit gives life."44

The third chapter also provides an indication of critical reflection as Capitein disagreed with Aristotle that slavery was introduced by natural law (ius naturae) by arguing that it was introduced by oppression, chance or the law of nature - eventually opting for chance as "accidents of fortune" necessitated by social and political stability. When Capitein drew his conclusion towards the end of chapter three, "that slavery in no way contradicts Christian freedom," he responded to the fact that the Netherlands had repealed slavery "not because of divine law" but "out of some sense of benevolence and clemency or for political expediency." 45

Grant Parker has convincingly argued that Stoicism played a major role in Capitein's argument for the compatibility of slavery with Christianity. ${ }^{46}$ Thus, he cites Cicero's "De Officiis"/"On Duties," which claims that the universe is an orderly "rational totality" and that human beings can achieve happiness when they live in accordance with this universal order. Similarly, Seneca defines a slave as "one who serves unwillingly" and notes that the "slavery of the soul" was more important than "physical slavery." Capitein's argument therefore seems to suggest that slavery has occurred since time immemorial, it is precipitated by "fortune" and not natural law and forms part of societal order that should not be tampered with but slave owners must take the dignity of slaves into account.

In her recent studies on "black cosmopolitans," Christine Levecq makes it clear that she does not consider Capitein's "Dissertatio" a defence of slavery, but a "rite of passage" bridging his academic training with his career as a minister or missionary teacher. It was also a means for Capitein to promote Christian mission to West Africans on the Gold Coast. ${ }^{47}$ This confronts us with the

44 Ibid., 105-107, 177.

45 Parker, Agony of Asar, 131.

46 Parker, Agony of Asar, 173, refers to the "canonical status of Cicero in Capitein's scholarly world."

47 Christine Levecq, Black Cosmopolitans: Race, Religion and Republicanism in an Age of Revolution (Charlottesville: University of Virginia Press, 2019), 2-3, 57, defines "cosmopolitanism" as a combination of "exposure and openness" to multiple and varied 
question of whether Capitein was a champion for slavery or a resisting mimic, or he was both.

\section{CHAMPION FOR SLAVERY OR RESISTING MIMIC?}

While contemplating whether Capitein was indeed a champion for slavery or a resisting mimic as reflected by his translations of seminal religious texts, one should also take note of his own preface to the translation of these religious texts as well as additional notes by the publisher to the reader to correct what was considered incorrect translations. ${ }^{48}$

In Capitein's own Preface "to the Christian reader," dated 3 August 1743, he depicted his translations as "laying the foundation of Christendom among our African and mulatto schoolchildren at the Castle of the West Indies Company at St, George d'Elmina." He further pointed out that his translation was not perfect "but rather that in the course of time it will be refined, so that God will open his door wider to us." 49

In their "Preface to the reader," the publisher felt obliged to issue a warning and agreed with Capitein that his translation "is not perfect," but also presumed in all fairness that certain Dutch words cannot be expressed "in the African language." For example, it is pointed out that the reference to "eternal life" in the conclusion of the Lord's Prayer is reformulated as discussed in the next paragraph. ${ }^{50}$ The publisher also noted that the translation of the Ten Commandments served as an example of translating in a manner that would make sense to the Fante audience. To take only one example, in the tenth commandment a horse and not a donkey is mentioned since the latter was not known by the people of the Gold Coast at that time. ${ }^{51}$ The first example might indicate the erroneous presupposition that African languages struggle to articulate abstract thought while the latter probably is a recognition of what concepts were known to the Fante audience.

John Ekem considers Capitein a pioneer in "Mother Tongue Biblical Hermeneutics" due to his translation of the "Lord's Prayer," "The Ten Commandments" and the "Apostles' Creed" into Mfantse, an important Akan

cultures and the ability to recognise and negotiate "spaces that were not determined by national identities or boundaries." Thus, Capitein was for her a good example of a "black cosmopolitan." This monograph was preceded by an article that viewed Capitein as a so-called "black cosmopolitan by Christine Levecq, "Jacobus Capitein: Dutch Calvinist and Black Cosmopolitan," RAL 44/4 (2013): 145-166.

48 Parker, Agony of Asar, 133-135.

49 Ibid., 133-134.

50 Ibid., 134.

51 Ibid., 134-135. 
dialect found in the Gold Coast. ${ }^{52}$ Capitein's translation of the Apostles' Creed into Mfantse shows several examples of his creative effort to contextualise the creed within its Elmina environment. ${ }^{53}$ In Articles 1 and VI of the creed, the usual translation, "God the Father Almighty" is changed to "God as Senior Father" to sound less authoritarian to an audience who was at the receiving end of slavery and exploitation. In Articles III and VIII, the "Holy Spirit" is rendered as "Good Spirit" and it seems likely that this reformulated reference to the Spirit (from "Holy" to "Good") recalls an association with revered ancestors possible whom the Mfantse considered to be the source of good fortune such as abundant harvest and procreation. Further, in Article III, Maria is described as a "girlchild" or a "young unmarried woman" and not as a "virgin," since according to Mfantse ethos, it was implied that she was a virgin. In Article IV, Capitein avoids any reference to the descent of Jesus into the world of the dead that was well known to the Mfantse and only mentions that Christ "experienced pain." No conclusive reason has been suggested for this reformulation, but "descending into death" might be implied since in the following Article V it is acknowledged that Christ "resurrected from the dead" and in Article XI, a similar assurance is given that "the dead will be raised." Of further note is Article X where "forgiveness of sins" is translated as "sin will be forgiven" that seems to suggest an eschatological expectation of a better future than the current horrors of enslavement and subjugation. In the concluding Article XII, the concept of "lifeeverlasting" is reformulated as, "And God will keep us well at all times," as an attempt to express holistic well-being that was valued by the Mfantse community.

What Dutch printers and ecclesial authorities regarded as "inaccuracies" might have been intentional attempts "to re-interpret source texts in the process of translation into an African language." 54 As Musa Dube has argued, vernacular translations of the Bible and religious documents can be seen as part of a decolonisation process that restores the languages that were denigrated and supplanted by the colonisers. ${ }^{55}$

Besides the translation of important religious texts, one should also take note of the sermons conducted by Capitein. In 1742, the same year he delivered his "Dissertatio," Capitein was asked to conduct several sermons for which he chose Ephesians 2:19 as text: "Consequently, you are no longer foreigners and aliens, but fellow citizens with God's people and members of God's

\footnotetext{
52 John David Kwamena Ekem, "Capitein's Contribution to Mother Tongue Biblical Hermeneutics: A Case Study of His Translation of the Apostles Creed into Mfantse," in Trajectories of Religion in Africa: Essays in Honour of John S. Pobee (ed. Cephas N. Omenyo and Eric B. Anum; Amsterdam: Rodopi, 2014), 395.

53 Ekem, "Capitein's Contribution," 400-408.

54 Ekem, "Capitein's Contribution," 408.

55 Musa W. Dube, Postcolonial Feminist Interpretation of the Bible (St. Louis: Chalice, 2000), 49.
} 
household..." ${ }^{56}$ His choice of text can be interpreted in different ways. On the one hand, it can be considered a grateful acknowledgement of him becoming a member of "God's household" in view of his baptism and ordination as minister in the Dutch Reformed Church. On the other hand, it can be seen as an apology for his future missionary work.

Can Jacobus Capitein be considered a "resisting mimic," despite his unquestionable advocacy of the qualified compatibility of physical slavery and Christianity? One should first keep in mind that the Guinea Coast of West Africa had a long history of international trading that stimulated the adoption of local culture by Europeans and created unique hybrid and creole Afro-European communities. ${ }^{57}$ Elmina, as one of the oldest European trading posts on the coast of West Africa was par excellence an example of a context in which a hybrid cultural identity such as characterised by Capitein could flourish and resist the hegemony of Dutch trading concerns. ${ }^{58}$ Capitein's attempted marriage to a local Fante woman and his immediate translation of seminal Christian documents into the local vernacular strongly suggest that he embraced being a "black cosmopolitan" 59 - similar to a hybrid identity that Franz Fanon referred to as "black skin and white masks" whereby the colonised imitate the language, dress, politics and cultural attitude of their colonisers. ${ }^{60}$ It seems likely that during Capitein's five-year stay in Elmina (1742-1747), the hybrid cultural context enhanced his own cultural hybridity and gave rise to a subtle critique of colonial practices that allowed at least some cultural emancipation to take place.

\section{E CONCLUSION}

Chaplain Jacobus Capitein has been either neglected or scorned by scholarship during the past century due to his erudite argument for the compatibility of slavery with Christianity and the remarkable popularity of his "Dissertatio" in the Netherlands in general and in the slave trading Dutch West India Company in particular. Tinyiko Maluleke was the first South African theologian to pay attention to Capitein whose life and work he used as an example of an "African

56 Dienke Hondius, “'No Longer Strangers and Foreigners, but Fellow Citizens': The Voice and Dreams of Jacobus Eliza Capitein, African Theologist in the Netherlands (1717-47)," Immigrants \& Minorities 28/2-3 (2010): 138.

57 Jose L. Nafafe, Colonial Encounters: Issues of Culture, Hybridity and Creolisation. Portuguese Mercantile Settlers in West Africa (Frankfurt: Peter Lang, 2007) points out that the first encounters between Europeans and West Africans did not immediately create hatred and hostility but that slavery and colonialisation gave rise to distrust and conflict.

58 Harvey M. Feinberg, “An Incident in Elmina-Dutch Relations," African Historical Studies 3/2 (1970): 362, describes how, just two years before Capitein's arrival in Elmina, the Dutch West Indian Company attacked Elmina in an onslaught that left more than 400 people dead and destroyed large parts of the town surrounding the castle.

59 Levecq, "Jacobus Capitein," 145-166.

60 Frantz Fanon, Black Skin, White Masks (New York: Grove Press, 2008). 
Protestant pioneer" who presented a "particular face of Protestantism" emerging in Africa that was different from the Protestant faces in Europe and North America. ${ }^{61}$

When one takes his eighteenth-century context into account, especially the extent to which slavery was prohibited in the Netherlands but allowed in the overseas Dutch trading posts, one should not be surprised by the ambiguous way his life has been evaluated. Grant Parker refers to Jacobus Capitein as a Kulturkuriosum ("the paradox of the learned African" that fascinated Europeans in the eighteenth and nineteenth centuries). ${ }^{62}$ This depiction of Capitein resonates with Ibram Kendi's concept of a "black exhibit," which is an individual chosen by white elites to become intellectual projects for proving and disproving the possibility of African genius. ${ }^{63}$ Maluleke has a more mundane description of the dynamics between Capitein (as a former slave) and Dutch mercantile interests when he described him as "a potent marketing tool" for the Dutch West India Company because he provided biblical and theological justification for their ongoing involvement in slavery. ${ }^{64}$

Therefore, Capitein can be perceived either as a sell-out to the mercantile interests of the DWIC who made huge profits from the flourishing slave trade triggered by the sugar industry in Brazil and the West Indies or as someone who

61 Tinyiko S. Maluleke, "Faces and Phases of Protestantism in African Contexts: The Jacobus Capitein Heritage," Studia Historiae Ecclesiasticae XXI /2 (2005): 1-35. Although the focus of this contribution is on the eighteenth-century context of Capitein in West Africa and the Netherlands, while honouring a biblical scholar from Nigeria, it would be amiss for me as a South African not to consider the need for more critical reflection on our own history of slavery. Robert Shell, "People of Bondage," in New History of South Africa (ed. Hermann Giliomee and Bernard Mbenga; Cape Town: Tafelberg), 59, provides statistics that indicate that slaves outnumbered "European free burghers" in the Cape throughout the eighteenth century. Despite their numerical significance, historical accounts of early Cape society ignore or neglect the impact of slaves. Karel Schoeman, Portrait of a Slave Society, 9, also comments on this matter: "While research into Cape slavery seems at present to be both fashionable and politically correct in certain circles, it is largely confined to the British period after 1795." In the same monumental study of eighteenth-century Cape slavery (1339 pages!), Schoeman remarks: "Slavery was to have a very long afterlife in South Africa, and subtly but profoundly to affect the further development of the country; and the investigation of slavery in the seventeenth and eighteenth centuries is therefore by no means an irrelevant exercise."

62 Parker, Agony of Asar, note 66, 165.

63 Ibram X. Kendi, Stamped from the Beginning: The Definitive History of Racist Ideas in America (New York: Nation Books, 2016), 122-124.

64 Maluleke, "Faces and Phases," 10. He further argues that the life of Capitein "demonstrates the entanglement between Protestantism, the commercial spirit and nascent Colonialism," that is, characteristics of "Protestantism as an imperial religion." Ibid., 12. 
used his cultural "hybridity" and intellectual ability to further the education of children from the Gold Coast (Ghana) in a school and take care of the local destitute children in an orphanage in Elmina. Why did Capitein put in such an effort to enable the education of the children of King Opuko Ware I of the Ashanti in the Netherlands? Was he motivated by his own experience of the advantages of a Dutch education or did he want to garner support from an influential local leader?

The fact of the matter is that Capitein revived the school at Elmina Castle that ceased to exist in 1661, more than eighty years before his arrival on the Gold Coast. ${ }^{65}$ The Dutch West India Company did not care much if the school remained inactive but Capitein resisted the existing apathy and soon established a school that provided education for the much-neglected local population.

An important question that remains is why did he write his "Dissertatio"? Was it just to comply with the requirements of the Hallet bursary or to curry favour within his adopted country and express his gratitude for the opportunities made possible by his surrogate Dutch family? ${ }^{66}$ One example of this underlying gratitude was the remarkable fact that Jacobus Capitein donated 300 guilders ( $25 \%$ of his annual salary) to his benefactor and patron Jacobus van Goch. ${ }^{67}$

One should at least consider his long-standing missionary ideal of the advancement of the preaching of the Gospel amongst the local inhabitants of the Gold Coast and that the subsequent conversion of local populations would lead to baptism. Despite several voices arguing for the abolishment of slavery, Capitein advocated at length that baptism still allowed the baptised to remain slaves - this ingenious argument countered the policy amongst slave owners not to allow their slaves to be baptised because that would inevitably lead to their manumission. This is probably a compromise to balance the continuation of slavery with all its financial benefits with the spreading of Christianity in a way that did not abolish slavery in Dutch overseas trading posts but at least made the education and conversion of slaves possible.

There seems to be enough evidence that Jacobus Capitein was not an unqualified champion for slavery in the Netherlands during the eighteenth-

65 M.A. Kwamena-Poh, "Capitein, Jacobus (A)," in The Encyclopaedia Africana Dictionary of African Biography Volume One: Ethiopia-Ghana (ed. L.H. OfusoAppiah; New York: Reference Publications, 1977).

66 Hondius, "No Longer Strangers," 131, 134, 140, considers "gratitude and apology" to be important elements of his "dissertation" because he was grateful for his Dutch education and wanted to provide an apology for the conversion of Africans that would not upset the lucrative slave trade of the Dutch West Indian Company.

67 F.L. Bartels, "Jacobus Eliza Johannes Capitein, 1717-47," Transactions of the Historical Society of Ghana 4/1 (1959): 10, points out that Capitein's annual salary of 1200 guilders per year was second only to the Governor or Director-General who earned 3600 guilders. 
century. His initial response to his adopted family and country was strongly influenced by a deep sense of gratitude for being freed from slavery and receiving an excellent education.

It is more complicated to provide a clear answer to the question whether he can be considered a "resisting mimic." Although the Dutch West India Company did not make the education of local black children a priority, Capitein within a few years tried to provide black children with seminal texts translated into their own vernacular, including the Lord's Prayer and the Ten Commandments. I am in full agreement with Kwame Bediako that "once the Bible was translated, African agency ... asserted itself," an agency that resisted the dominant Dutch colonial culture Capitein once mimed to perfection! ${ }^{68}$

Furthermore, Maluleke is correct to point out that vernacular translations of the Bible and creeds, pioneered by Capitein in West Africa, "inaugurated an African intellectual culture" that stimulated the growth of Christianity in Africa and the emergence of African Independent Churches. ${ }^{69}$ Capitein's hybrid identity emerged in Elmina as a combination of his ongoing affiliation with Dutch culture and of resisting the oppressive colonial situation with his translations into the local vernacular for the benefit of the Fante schoolchildren. ${ }^{70}$

Capitein's interpretation and application of Old Testament texts within his "Dissertatio" reveal an interesting combination of different theological trends prevalent in the eighteenth century. His classical erudition and frequent referencing of Greek and Roman philosophers indicate his exposure to rationalism. His differentiation between the Old and the New Covenant smacks of dispensationalism but, overall, he seems to adhere to the "plain sense" of the biblical text ("sensus plenior"). He also did pioneering vernacular translations that adapted biblical and creedal texts to the frame of reference of his African target audience - amidst the criticism of his publisher!

David Adamo dedicated a long academic career to further quality theological education in West Africa that resisted the lingering colonial neglect of African contexts. Jacobus Capitein seems to provide an interesting, if ambiguous case study of an African scholar who used his Western education to face up to the challenges of colonialism, one of the important items remaining on the agenda of biblical studies in Africa. Capitein was a pioneer in the

68 Kwame Bediako, Christianity in Africa: The Renewal of a Non-Western Religion (Maryknoll: Orbis, 1995).

69 Maluleke, "Faces and Phases," 16.

70 Homi K. Bhabha, The Location of Culture (London: Routledge, 1994), 159, describes "hybridization" as the juxtaposition of colonial and indigenous ideas and, in a similar vein, "hybridity" is seen as a subtle challenge to the colonial power that combines affiliation with resistance - allowing Capitein to become a resisting mimic. 
vernacular translation of important parts of the Bible and seminal Christian documents - a crucial starting point for the decolonisation of biblical studies. ${ }^{71}$

\section{F BIBLIOGRAPHY}

Adamo, David T. “African Biblical Studies: Illusions, Realities and Challenges." In die Skriflig 50/1 (2016): 1-10.

Amponsah. David K. "Christian Slavery, Colonialism and Violence: The Life and Writings of an African Ex-slave, 1717-1747." Journal of Africana Religions 1/4 (2013): 431-457.

Balkenhol, Markus. "Silence and the Politics of Compassion. Commemorating Slavery in the Netherlands." Social Anthropology 24/3 (2016): 278-293.

Bartels, F.L. "Jacobus Eliza Capitein, 1717-47." Transactions of the Historical Society of Ghana IV/1 (1959): 3-13.

Bediako, Kwame. Christianity in Africa: The Renewal of a Non-western Religion. Maryknoll: Orbis, 1995.

Bhabha, Homi K. The Location of Culture. London: Routledge, 1994.

Capitein, Jacobus E.J. Dissertatio Politico-Theologica de Servitute, libertati christianae non contraria. Leiden: Academiae Typographos, 1742.

. Staatkundig-Godgeleerd Onderzoekschrift over de Slaverny, als niet strydig tegen de Christlyke Vryheid. 3rd ed. Amsterdam: G de Groot, 1742.

Dube, Musa W. Postcolonial Feminist Interpretation of the Bible. St. Louis: Chalice, 2000.

Dyck, Andrew R. A Commentary on Cicero, 'De Officiis.' Ann Arbor: University of Michigan Press, 1996.

Eekhof, Albert. "De Negerpredikant Jacobus Elisa Joannes Capitein, Bijdrage tot de kennis van onze koloniale kerkgeschiedenis. Nederlandsch Archief voor Kerkgeskiedenis XII/2 (1916): 138-174, 209-276.

Ekem, John D.K. "Jacobus Capitein's Contribution to Mother Tongue Biblical Hermeneutics: A Case Study of his Translation of the Apostles' Creed into Mfantse." Pages 395-411 in Trajectories of Religion in Africa. Edited by Cephas N. Omenyo and Eric B. Anum. Amsterdam: Rodopi, 2014.

Fanon, Frantz. Black Skin, White Masks. New York: Grove Press, 2008.

Feinberg, Harvey M. "An Incident in Elmina-Dutch Relations." African Historical Studies 3/2 (1970): 362.

. "New Data on European Mortality in West Africa: The Dutch on the Gold Coast, 1719-1760.” Journal of African History 15 (1974): 357-371. . "Africans and Europeans in West Africa: Eliminians and Dutchmen on

the Gold Coast during the Eighteenth Century." Transactions of the American Philosophical Society 79/7 (1989): 1-186.

71 The decolonisation of biblical studies in South Africa requires more rigorous historical analysis of our past engagement with the Bible when the Bible was utilised as a "tool of imperialism," by not only the British imperialism of the nineteenth century but also the impact of Dutch East India Company's mercantile capitalism on Cape slavery during the seventeenth and eighteenth centuries. This point of view resonates with the recent publication by Gerald West, The Stolen Bible: From Tool of Imperialism to African Icon (Pietermaritzburg: Cluster Publications, 2016). 
Frei, Hans W. The Eclipse of Biblical Narrative. A Study in Eighteenth and Nineteenth Century Hermeneutics. New Haven: Yale University Press, 1974.

Goldenburg, David M. Black and Slave: The Origins and History of the Curse of Ham. Studies of the Bible and Its Reception. Volume 10. Berlin: De Gruyter, 2017.

Hondius, Dienke. “'No Longer Strangers and Foreigners, but Fellow Citizens': The Voice and Dreams of Jacobus Eliza Capitein, African Theologist in the Netherlands (1717-47)." Immigrants and Minorities 28/2-3 (2010): 131-153.

Kendi, Ibram X. Stamped from the Beginning: The Definitive History of Racist Ideas in America. New York: Nation Books, 2016.

Kpobi, David N.A. Mission in Chains: The Life, Theology and Ministry of the Ex-slave Jacobus EJ Capitein (1717-1747). Zoetermeer: Boekencentrum, 1993.

Kwamena-Poh, M.A. "Capitein, Jacobus (A)." Pages 20-21 in The Encyclopaedia Africana Dictionary of African Biography Volume One: EthiopiaGhana. Edited by L.H. Ofuso-Appiah. New York: Reference Publications, 1977.

Leupe, PA. “De Latijnse Dissertatie van den Predikant J.E.J Capitein. 1742.” Bijdragen tot de Taal-, en Land-Volkenkunde van Nederlandsch-Indië 28/4 (1880): 609610.

Levecq, Christine, "Jacobus Capitein: Dutch Calvinist and Black Cosmopolitan." Research in African Literatures 44/4 (2013): 145-166.

. Black Cosmopolitans: Race, Religion and Republicanism in an Age of Revolution. Charlottesville: University of Virginia Press, 2019.

Maluleke, Tinyiko S. "Faces and Phases of Protestantism in African Contexts: The Jacobus Capitein Heritage.” Studia Historiae Ecclesiasticae XXI/2 (2005): 135.

Nafafe, Jose L. Colonial Encounters: Issues of Culture, Hybridity and Creolisation. Portuguese Mercantile Settlers in West Africa. Frankfurt: Peter Lang, 2007.

Parker, Grant. The Agony of Asar: A Thesis on Slavery by the Former Slave, Jacobus Elisa Johannes Capitein 1717-1747. Princeton: Marcus Wiener, 2001.

Pleij, Herman. Het Nederlandsche Onbehagen. Amsterdam: Prometheus, 1991.

Rathlef, Ernst L. Geschichte Jeztlebender Gelehrten, als eine Fortsetzung des Jeztlebenden Gelehrten Europa. Zelle: Deetz, 1743.

Schama, Simon. The Embarrassment of Riches: An Interpretation of Dutch Culture in the Golden Age. New York: Alfred Knopf, 1987.

Schoeman, Karel. Portrait of a Slave Society: The Cape of Good Hope, 1717-1795. Pretoria: Protea Book House, 2012.

Shell, Robert. "People of Bondage." Pages 53-59 in New History of South Africa. Edited by Hermann Giliomee and Bernard Mbenga. Cape Town: Tafelberg, 2007.

Strodtmann, Johann C. Das Neue Gelehrte Europa. Wolfenbüttel: Th XII, 1758.

West, Gerald. The Stolen Bible: From Tool of Imperialism to African Icon. Pietermaritzburg: Cluster Publications, 2016.

Hendrik L. Bosman, Old and New Testament, Stellenbosch University, hlb1@sun.ac.za, ORCID: https://orcid.org/0000-0002-2439-8119 